\title{
THE DEATH OF CLEOPATRA
}

\begin{abstract}
The last days and death of Cleopatra and Mark Antony are reviewed. Antony died a slow death after an initially unsuccessful suicide attempt by way of a stab wound to the abdomen. It is argued that Cleopatra (and her two servants) probably committed suicide through poisoning, rather than the bite of an asp (viper) as is popularly believed. Death occurred very rapidly and the bodies showed no recognisable snake bite wounds. Fatal viper bites are characteristically associated with prominent, swollen and haemorrhagic wounds. Cobras may cause rapid death in spite of minor bite wounds, but in order to kill three adults, the snake would have to be large. Legend has it that the reptile was smuggled to Cleopatra in a small basket of figs, which would not have been possible with a large snake.
\end{abstract}

\section{INTRODUCTION}

The relationship between Cleopatra and Mark Antony is one of the best-known love stories in history, and their double suicide in the year $30 \mathrm{BC}$ has been dramatised many times through the centuries. Writers and historians have created such diverse images of Cleopatra that it is difficult to distinguish between reality and myth — the capable and beloved last Queen of Egypt versus the romanticised version of a seductive, ambitious, beautiful woman manipulating all around her to her own advantage.

This article, which focuses on the last days of Cleopatra and Antony, draws much of its evidence from the writing of Plutarch, a Greek who lived roughly a century after Cleopatra and based his information on contemporary texts which are no longer extant, and on the memoirs of Cleopatra's physician, Olympus. Comprehensive surveys of the relevant sources by Hughes-Hallett (1997:57-94) and Marasco (1995:317-325) have shown that the Roman writers, sympathetic towards Octavian (who overcame Antony), intentionally depicted Cleopatra in a negative light. Their versions of the story must thus be read with reservation. 


\section{BACKGROUND ON CLEOPATRA}

Cleopatra VII, born in $69 \mathrm{BC}$, was the third child of Ptolemy XII, the king (Pharaoh) of Egypt and a direct descendant of Ptolemy I, the Macedonian general of Alexander the Great, who became king of Egypt in $323 \mathrm{BC}$. The Ptolemies adopted the Pharaonic practice of marrying brothers and sisters, so that Cleopatra may be considered to have been of predominantly Greek descent. In her day, Egypt's political power had been attenuated but it was still the richest state in the Eastern Mediterranean.

There are no original descriptions of Cleopatra, but from information available to him Plutarch (Antony c.27) tells us that she was not particularly attractive (as is confirmed by her image on coins ${ }^{1}$ ), but that she was a particularly cultured, charming person, multilingual and with a strikingly musical voice. According to all the evidence she was, unlike her father, a beloved and capable ruler who administered her country efficiently, loyally and with considerable political insight.

In $51 \mathrm{BC}$, at the age of eighteen, she and her ten-year-old brother Ptolemy XIII were married and became co-rulers of Egypt. Three years later there was a power struggle and with the help of Julius Caesar, who was in Egypt by chance, she retained her throne. They became lovers and she bore him a son, Caesarion (meaning "Little Caesar"). In 44 BC Caesar was murdered in Rome and a civil war broke out. Octavian (later known as Augustus Caesar) and Mark Antony emerged as joint victors, but still rivals. In terms of their agreement, Antony was given control over the Eastern Roman Empire. He embarked on a partnership with Cleopatra in order to obtain Egypt's wealth for his intended military programme. They became lovers and she bore him twins, followed by another son. In $40 \mathrm{BC}$, however, while she was pregnant, he left her for a political marriage to Octavia, the sister of Octavian. The marriage lasted only three years, and in $37 \mathrm{BC}$ he returned to Alexandria. From this point onwards, he saw Egypt and his collaboration with Cleopatra as his power base in his growing conflict with Octavian. An ambitious campaign against Parthia ended disastrously for Antony, and in time Rome turned against him. In the naval battle

1 Hughes-Hallett (1997:31). 
of Actium in $31 \mathrm{BC}$ the combined fleets of Cleopatra and Antony were comprehensively defeated and they fled to Alexandria. Octavian and his army reached the city the following year for the final confrontation.

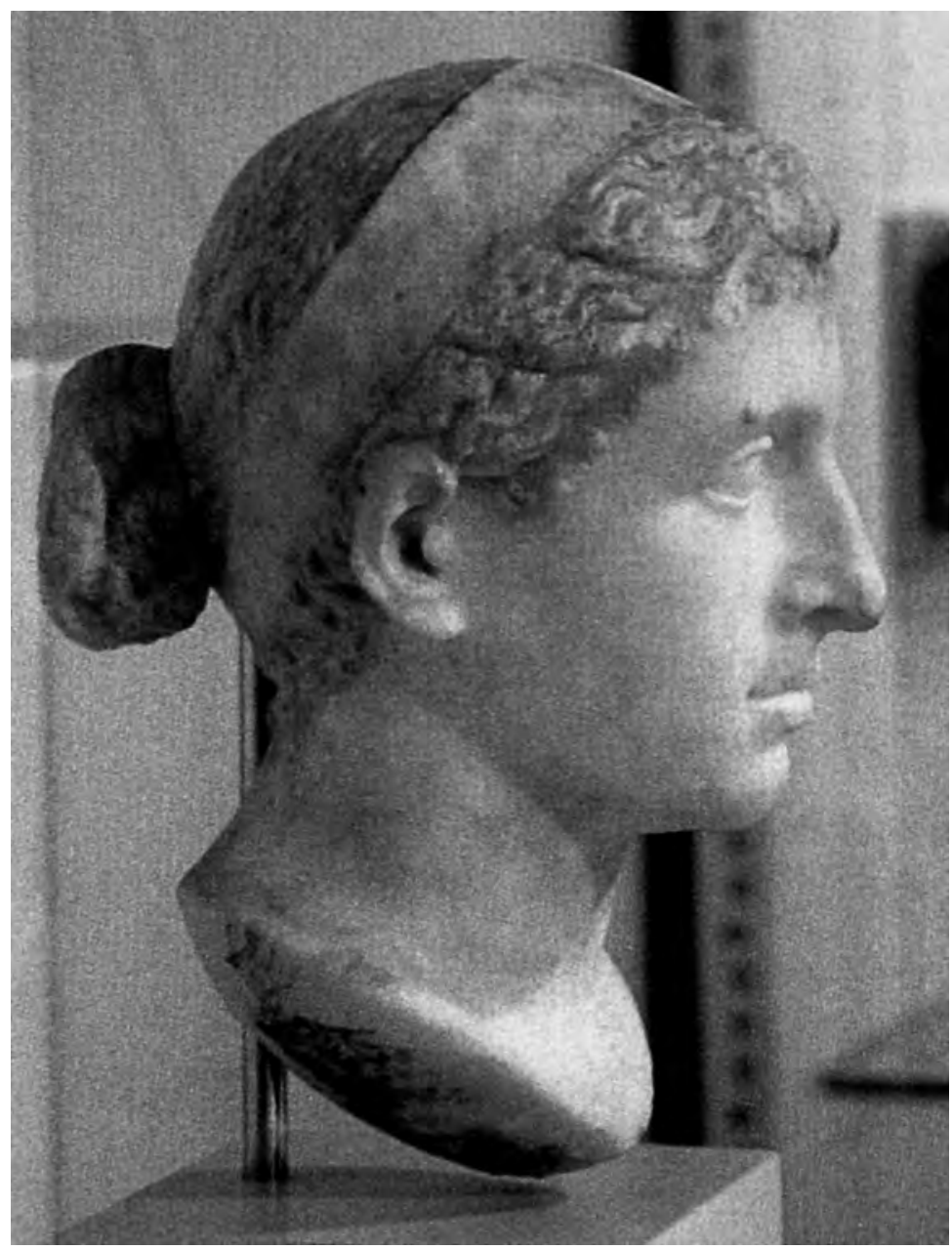

Figure 12: Cleopatra. 


\section{THE LAST DAYS}

On her return to Egypt Cleopatra, according to Plutarch (Antony c.71), arranged a series of extravagant receptions as though she and Antony had won the battle of Actium and had no military threat at hand. At the same time, however, she was negotiating with a deputation from Octavian, who was willing to make peace with her but insisted that Antony be delivered up to him. She refused, probably because she realised that the Romans were primarily after the wealth of Egypt and that she would be humiliated as part of the traditional triumphal parade which Octavian would hold in Rome. It is uncertain to what extent her love for Antony influenced Cleopatra's behaviour at times like this. She was undoubtedly a very pragmatic leader and person - her own interests and those of her family and her country were extremely important to her. But the research done by Hughes-Hallett (1997:136137) confirms the opinion of romantics over the years: that there was indeed a particular bond of love between Cleopatra and Antony.

Plutarch (Antony c. 71) tells us that Cleopatra had been involved in testing various poisons on convicted criminals in order to determine which caused the most acceptable death, in case she decided to take her own life. Marasco (1995:317-325) believes that these allegations came mainly from Roman sources which favoured Octavian and wanted to sully Cleopatra's image after her death. This would also tally with the contemporary Roman criticism of the famous medical school at Alexandria, that it was involved in vivisection and other experiments on living human beings.

As the earthly representative of the goddess Isis, Cleopatra had had a series of funeral chambers and imposing monuments built next to the temple of Isis. At this stage she brought her treasures to one of these monuments, along with a large supply of firewood. Octavian became concerned that she was contemplating destroying all her valuable possessions and resumed serious negotiations, but no satisfactory conclusion could be reached.

In the spring of $30 \mathrm{BC}$ Octavian's army reached Alexandria. Antony's counter-attack was initially successful, but the following day his fleet and cavalry deserted to Octavian. Antony fell back to the city, an embittered man, and with the unreasonable suspicion that Cleopatra 
had been a party to the treason. Hearing all this, she and two of her handmaidens fled to the monument, closed the heavy door and sent Antony a message that she was dead. Despairing, Antony instructed his bodyguard, Eros, to end his life. Eros drew his sword but turned it on himself instead, leaving Antony to commit suicide by falling on his own sword. He did not die immediately, but lay in pain and despair, begging his servants to finish him off.

Cleopatra was informed of this and immediately sent her secretary, Diomedes, to bring Antony to her. She refused to open the door of the monument, but lowered ropes from a second-storey window. Plutarch describes the pathetic scene of the queen and her two handmaidens raising Antony with great difficulty, in view of a crowd of sympathetic supporters, and laying him on her bed. Proclaiming her love, she tore her garments and strewed them over him. Weeping, she smeared her face with his blood and beat her breasts continually, causing severe lacerations. Antony asked for wine, drank it, bade her farewell, and finally advised her on which of the Roman legates she could trust, before passing away. He was 53 years old.

Once Octavian heard of the death of his erstwhile colleague and opponent, he did all in his power to extricate Cleopatra from the monument alive and to seize her treasure. He sent envoys to the monument to negotiate (through the locked door) with Cleopatra about her future. When she descended to the ground floor to speak to them, three Romans surreptitiously entered the monument by climbing a ladder to the open window through which Antony had recently been hoisted in. Cleopatra attempted to commit suicide with her own dagger, but she was overcome and her clothes were carefully searched to be sure that she was not hiding any poison. After this, Octavian ordered that she be placed under guard, although with respect and dignity, and taken to quarters fit for a queen. Her children were also sympathetically treated by the Romans, although Caesarion was killed after her death because a descendant of Julius Caesar could have posed a threat to Octavian.

Many high-ranking officials requested the honour of burying Antony, but Octavian gave Cleopatra a free hand to arrange the funeral with royal ceremony in accordance with her wishes. Shortly after this, however, she fell ill with a high fever as a result of infection in the 
wounds on her breasts. She embarked on a fast and asked her physician, Olympus, to end her life. When Octavian threatened to hurt her children, however, she began to eat again and accepted treatment. Shortly after this, Octavian paid her a historic visit about which there has been much speculation. It is often suggested that she attempted to seduce him, but in fact she was quite humble and unadorned, prostrating herself before him. She was clearly not yet well, and the wounds on her breasts were clearly visible through her single garment. Octavian did not wish to make any significant concessions, but did assure her that he would treat her and her family with honour. Cleopatra then handed him a list of her personal treasures.

A confidante in the Roman camp informed Cleopatra that arrangements were being made to transport her and her children to Rome within the next three days. She asked permission to visit Antony's grave one last time, which was granted. She was carried there, paid her last mournful respects, and returned to her quarters. There she bathed, put on the regalia of the religion of Isis and gave orders for a grand feast to be prepared. At this time an old peasant brought her a basket of figs, which the guards viewed as innocuous and allowed to be delivered to her. Then she despatched a letter to Octavian, dismissed all her staff except for Charmian (her lady-in-waiting) and Iras (her hairdresser) and closed the doors. When Octavian read the letter containing her final, rather pathetic requests, including that she be buried alongside Antony, he realised what she was about to do and rushed to her quarters. It was already too late: Cleopatra, strikingly clothed in the regalia of the goddess, lay dead on her bed. Iras was already unconscious, while Charmian was attempting in her last moments to place a coronet on the head of her queen.

Octavian saw to it that she was interred next to Antony and with full royal pomp and ceremony. The two women who had died with her were also buried with honour.

Cleopatra was 39 years old when she died. She had been queen of Egypt for almost 22 years, and for this historical icon of wily sensuality the truth is probably that, besides an unconsummated marriage (to her brother) she had only two lovers in her lifetime - Julius Caesar (for 3 months) and Mark Antony (intermittently for 13 years). Thus the Ptolemaic era, the last dynasty of ancient Egypt, came to its close. 


\section{CAUSE OF DEATH}

\subsection{The snakebite theory}

Plutarch (Antony c.86) is responsible for the popular belief that Cleopatra and her two handmaidens committed suicide by allowing themselves to be bitten by an asp which had been smuggled in to them, concealed in the basket of figs. An alternative suggestion was that she could have kept the snake in a vase for just such a purpose. However, Plutarch goes on to say that no snake was found in the room (although a suspicious trail was noticed on the ground outside the window) and that no bite-marks could be found on the victims, apart from very small punctures on Cleopatra's forearms. It would have taken a large snake, or more than one, to kill three adults so speedily, and this does not tally with the story of the basket of figs.

Hughes-Hallett (1997:139-140) has indeed argued convincingly that the snakebite theory is problematic. Various North African adders could have been used - in addition to Cerastes vipera (the so-called "Cleopatra's asp"), there are also Vipera berus, Vipera aspis and Cerastus cornutus (the "horned" adder). However, in the case of each of these species the area surrounding the bite is characterised by severe pain, swelling and subcutaneous bleeding. Death ensues only in cases showing prominent signs and symptoms, while Cleopatra, as we have seen, had no significant bite marks. On the other hand, if the snake were not an adder but a cobra (for example the Egyptian cobra, Naja haja, locally known as uraeus), an inconspicuous bite could swiftly lead to paralysis and death. The cobra was the emblem of the Egyptian royal house as well as being the sacred creature associated with the goddess Isis. Thus the cobra may well have had a particular symbolic significance for Cleopatra. Galen (De theriaca ad Pisonem c.8 K.XIV.237) also notes that death by snakebite was a recognised (and humane) method of execution in ancient Alexandria. Again, however, in order to bring about the speedy deaths of three adults, the cobra would have had to be at least 1.5, if not 2 meters in length (Hughes-Hallett 1997:140).

M. A. Wes (2000:222-224) has offered the interesting hypothesis that the snakebite theory could have originated as a result of popular misunderstanding at the time of Octavian's triumphal parade through 
The death of Cleopatra

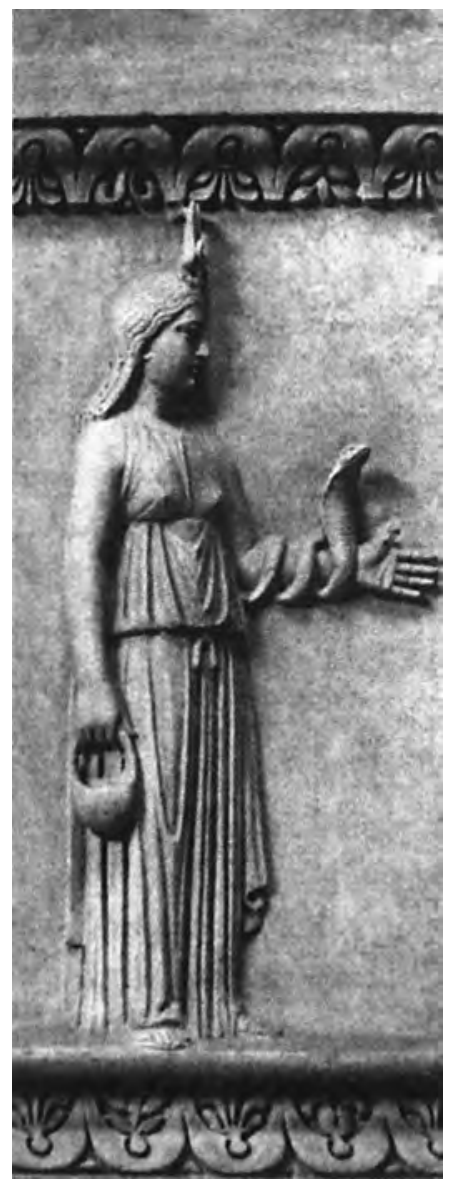

Figure 13: A priestess of Isis, dressed as the goddess with a cobra around her left arm.

Rome. An image of Cleopatra was displayed in the procession, wearing the robes of Isis and with the goddess's traditional armlet (a coiled snake) on her forearm (Fig. 13). Roman spectators ignorant of Egyptian religious symbolism might have interpreted this as suggesting that her death had been caused by a snake - in fact, three Roman poets 
who were contemporaries of Cleopatra and could have witnessed the triumphal procession (Virgil, Horace and Propertius ${ }^{2}$ ), mentioned snakes when referring to her death.

\subsection{The poisoning theory}

Plutarch (Antony c.86) also mentions the possibility that Cleopatra and her handmaidens could have died of poison hidden in a hollow hairpin. For parallels one need not turn to the plots of James Bond films - the Greek orator Demosthenes, the Carthaginian general Hannibal and the Eastern king Mithradates spring to mind as famous figures who committed suicide in a similar way. ${ }^{3}$ A very virulent poison, taken first by Cleopatra and then by Charmian and Iras, could then explain how they died so swiftly and without any wounds. In many ways this simpler explanation is more acceptable than the exotic theories concerning snakebite. It has been alleged that the first Pharaoh, Menes, kept a garden of poisonous plants, and that the Egyptian royal house probably remained well-informed about the effects of various poisons (Bloch 1987:761-763). As has been mentioned, Roman authors in particular alleged that Cleopatra had a superior knowledge of poison and its effect on human victims (Plutarch, Antony c.71). In the absence of more detailed clinical information it is difficult to speculate about which poison may have been used. However, the fact that the three women apparently died swiftly and without much pain or discomfort suggests an agent which would cause acute paralysis, or a cardiotoxin. Monkshood (containing aconite), for example, which was used by the emperor Nero (among others) to poison his victims, falls in this category (Retief \& Cilliers 2000:15-17).

And thus, for the serious historian, the death of Cleopatra will remain an unsolved mystery, while the popular mind is likely to remain fascinated by romanticised and exotic representations of the last Queen of the Nile and her Roman general.

2 Virgil, Aeneid VIII. 697; Horace, Ode 1.37.27; Propertius III.11.30, 39 and 53.

3 Demosthenes had poison hidden in a pen (Plutarch, Demosthenes 29.3); Hannibal had poison hidden in a ring (Suetonius, De viris illustribus 42.6), and Mithradates had poison in the scabbard of his sword (Appian, Mithradatica III). 


\section{REFERENCES}

\section{APPIAN}

1912. Roman history (transl. H. White). London: W. Heinemann. Loeb Classical Library.

\section{BLOCH H}

1987. Poisons and poisoning: implication of physicians with man and nations. Journal of the National Medical Association 79(7):761-763.

\section{GALEN}

1964. De theriaca ad Pisonem 1964. In: C.G. Kühn, Claudii Galeni opera omnia. Vol. XIV. Hildesheim: Georg Olms Verlagsbuchhandlung.

\section{HORACE}

1927. Odes and epodes (transl. C.E. Bennett). London: W. Heinemann. Loeb Classical Library.

\section{HORSTMANSHOFF H F J}

1992. Gemeen goed. Lampas 25(1):32-56.

\section{Hughes-Hallett L}

1997. Cleopatra: histories, dreams and distortions. Pimlico: Bloomsbury Publ.

\section{MARASCO G}

1995. Cleopatra e gli esperimenti su cavie umane. Historia 44:317-325.

\section{PluTARCH}

1920. Parallel lives (transl. B. Perrin). London: W. Heinemann. Loeb Classical Library Vol. VII: Demosthenes and Cicero. Alexander and Caesar and IX: Demetrius and Antony. Pyrrhus and Gaius Marius.

\section{PROPERTIUS}

1990. Elegies (transl. G.P. Goold). London: W. Heinemann. Loeb Classical Library.

\section{Retief F P \& Cilliers L}

2000. Vergiftiging in antieke Rome. S.A. Tydskrif vir Natuurwetenskap en Tegniek 19(1):10-17.

\section{SUETONIUS}

1914. Lives of the Caesars. Lives of illustrious men. London: W. Heinemann. Loeb Classical Library Vol. II.

\section{VIRGIL}

1966. The Aeneid VII-XII (transl. H.R. Fairclough). London: W. Heinemann. Loeb Classical Library.

\section{WeS M A}

2000. Diva Cleopatra. Historische en onbistorische verhalen. Groningen: Voltaire. 